\title{
Transnationality of Asian American Literature
}

\author{
Ilgu Kim \\ Hannam University, Daejeon, South Korea
}

\begin{abstract}
Since Asian American writings came into existence in the early 1970s, the American dream has been a recurring main theme in Asian American literature. However, the protagonists in Asian American literature often face more disillusion or discrimination than satisfaction and gratitude toward their long-accumulated achievements in the states while getting nearer to the realization of American dream. The so-called 'glass ceiling' is still functioning as the obstacle to many young, strenuous, talented Asian Americans. In my paper I analyze these successful yet still frustrated Asian American heroes or heroines through novels written by some Asian American representative writers such as Carlos Bulosan, Amy Tan, Maxine Hong Kingston, Hisaye Yamamoto, John Okada, Chang-Rae Lee, Jhumpa Lahiri, Don Lee and Gish Jen. And I argue that these delayed American dreams in Asian American literature are not only caused by the white mainstream society's biased views about the Asian Americans but also by a dialectic process to the Asian Americans' their own nomadic or transnational tendency. To show this inter/independent characteristics of the successful/frustrated Asian Americans in Asian American fiction, I will use the following texts as the mainstay to support my arguments: Carlos Bulosan's America Is in the Heart, Amy Tan's The Joy Luck Club, Maxine Hong Kingston's The Woman Warrior: Memoirs of a Girlhood among Ghosts, Hisaye Yamamoto's Seventeen Syllables, John Okada's No-No Boy, Chang-Rae Lee's Native Speaker, Jhumpa Lahiri's Unaccustomed Earth, Don Lee's "Yellow," Gish Jen's Typical American and Minae Mizumura's A True Novel. For the transnationality of Asian Americans, I will also use some nonfiction books such as Gish Jen's Tiger Writing: Art, Culture, and the Interdependent Self, Minae Mizumura's The Fall of Language in the Age of English and Chang-Rae Lee's "Mute in an English-Only World." This paper also focuses on the Asian American identity's diasporic variations based on "neither/nor logic" related with the imagined community. Overall, my paper explores East-West comparison and combination in self inter/independent construction, and how this transnationality widely affects Asian American literature and the Asian American's dynamic cultural formation in America.
\end{abstract}

Key-Words: Asian American, assimilation, acculturation, diaspora, atopology, transnationality

\section{Transplant into a New ground}

In her second collection of short stories entitled Unaccustomed Earth, Jhumpa Lahiri, by using two impressive extracts, aptly expresses the beginning and the current situation of an Asian American family's life in America. First extract she uses is from a brief quote from Nathaniel Hawthorne's "The Custom-House": "My children will have had other birthplaces, and, so far as their fortunes may be within my control, shall strike their roots into unaccustomed earth." Likewise, all Asian American writers' writings are in a way the records of the Asians' striking roots into unaccustomed earth of America. However, Hawthorne's other sentence tosses a question about the flowering of this rooting: "Human nature will not flourish, any more than a potato, if it be planted and replanted, for too long a series of generations, in the same worn-out soil." Contrary to their immigrant parents' hope for new places free of their ancestors and the past, the children of Asian families in America in the story still suffer from the invisible pressure from mainstream society. Lahiri in a short story of "Only Goodness" introduces an American Bengali family and their alcoholic son Rahul. Like many Asian children, Rahul successfully enters a good university, Cornell in this story, to come up to his parents' expectations. Yet his secret drinking during high school days by his sister Sudha's suggestion finally leads him to the dismissal from college. Rahul later visits Sudha who is successfully living in London with her British husband and their baby. However, by leaving Sudha's infant son alone in the bathtub, Rahul proves again that he could not yet recover from his chronic alcoholism. This kind of Asian family's second generation's descent into depression and anxiety is not unusual in Asian American literature. The first generation parent of Asian family often think that their hard working can be rewarded with providing their children with a paradise, the realization of their Asian American dream: 
"Depression" was a foreign word to them, an American thing. In their opinion their children were immune from the hardships and injustices they had left behind in India, as if the inoculations the pediatrician had given Sudha and Rahul when they were babies guaranteed them an existence free of suffering. (Lahiri)

However, the second generation children soon feels that their parents' burden is not erased but passed down to them just to a lesser extent. In "Mute is an English-Only world," Chang-rae Lee remembers a bitter experience caused by his mother's communication trouble:

My mother pulled us forward and began searching the cases, but the oxtails were nowhere to be found. The man, his big arms crossed, sharply said, "Come on, lady, whaddya want?" This unnerved her, and she somehow blurted the Korean word for oxtail, soggori. The butcher looked as if my mother had put something sour in his mouth, and he glanced back at the lighted board and called the next number. Before I knew it, she had rushed us outside and back in the wagon, which she had double-parked because of the crowd. She was furious, almost vibrating with fear and grief, and I could see she was about to cry.

Although Chang-rae Lee as a child talented in mimicry and language, helps speaking in his mother's shopping yet we know that he himself cannot be an efficient cultural interpreter in this special day. (Suki Kim's The Interpreter is the same case). As the recurrent symptom of minority culture's assimilation process into the mainstream culture, the second generation children's conundrum repeats in Hisaye Yamamoto's "Seventeen Syllables." Here Rosie's mother's grief is deepened not only by her husband's violence but also continued in her teenage Japanese-American daughter. Abandoned and miscarriaged in Japan, Rosie's mother rather chooses to be a picture bride of Japanese laborer in America and tries to find her consolation in writing haiku, the seventeen-syllable Japanese classic poetry, and wins a grand prize in haiku contest hosted by a local Japanese newspaper company. However, angry and jealous at his wife's talk with the editor instead of helping him in the farm, Rosie's father breaks and burns the beautiful prize picture of seascape. Moreover, sexually awaking Rosie is also asked not to be married to a Mexican boy whom she falls in love with by her mother in despair.

The protagonist Ralph Chang in Gish Jen's Typical American is a Chinese American professor who decides to become a typical American in order not to be a victim of this Asian minority culture. After having left China to the states by winning a grant in 1947 he has worked hard in engineering and obtains his tenure in an American university. His wife Helen, his sister Theresa and him all become American citizen and buy a decent real estate. After having a girl, Ralph and Helen let their daughter wear the same clothes as American children and take care more in grooming the lawn for their new home. They go together to baseball games and Ralph enjoys a nice relation with Cammy, the red-haired department secretary. Ralph gradually seems to change into a typical American yet the superficial ease of American ways does not continue long. They still hear in the ballpark what Yankees fans shout to them "go back to your laundry" and their newly purchased house shows signs of fissures. Furthermore, persuaded by his self-made-millionaire friend Grover Ding, Ralph embarks on an enterprise almost giving up studies to get quicker and closer to American dream. Theresa's pursuit of medical career also makes their Americanization accelerated. Yet Grover's temptation toward Helen and Theresa's car accident by Ralph make them rethink what their efforts to become typical Americans means. Ralph realizes that no one is typical and he must adapt himself uniquely to the complexity of the new cultural context.

Chang-rae Lee's The Native Speaker focuses on this specificity of an Asian American. In many ways, the protagonist Henry Park is in sharp contrast with the typical Americanization. Henry Park's life looks like almost the post-Ralph version. Henry has already lived like a white man after his mother's death and he refuses to use his Korean name Byungho. As a strong assmilationist he intentionally or subconsciously marries Lelia, a white woman and settles into a white town. But his son Mitt suddenly dies of the neighborhood children's mean prank and his wife in disarray dumps him leaving a message that he is a spy, emotional alien. The secret information company where Henry Park works makes Henry's identity more delicate. While searching into information about John Kwang, a charismatic New York mayor candidate, Henry feels a strong sympathy with John Kwang who effectively uses Korean culture in American political campaign. Yet Henry's media exposure of John Kwang's use of gye, a kind of traditional private fund popular among Koreans, turns out negatively enough to cause John Kwang's sheer panic and drunk driving. Henry gives up his spying job and returns to his wife who is now helping poor and illegal children to learn English. Henry's concern with the non-native children's original 
names and pronunciation reflects that Henry's assimilation is undergoing a transition toward a overlapped shade of nationalism or ethnic identity.

\section{Acculturation of the Second Generation}

If writings about the first generation immigrants often emphasize their struggle for assimilation into the mainstream culture, the second generation children raise more questions of acculturation. Acculturation means acquiring the capability to function within the dominant culture while retaining one's original culture. In contrast with the assimilation which is a process of cultural absorption of a minority group into the main cultural body, acculturation broadly deals with changes in cultural attitudes between two distinct cultures. Therefore, acculturation for the second generation can be revealed either biculturalism with denial of neither or observance of ethnic identity thorough the rejection of the dominant culture.

If we go back to the early Asian American literature, we can see a more strident confliction between the biculturalism and ethnic tradition. John Okada's No-No Boy and Carlos Bulosan's America Is in the Heart are both writings about American dystopia. If Carlos's illusion of American dream is broken by the brutality and injustice against Asian minority, Ichiro Yamada's disillusionment comes from the following two questions know as 'loyalty questionaires' by the War Relocation Authority (WRA).

27) "Are you willing to serve in the armed forces of the United States on combat duty wherever ordered?"

28) "Will you swear unqualified allegiance to the United States of America and faithfully defend the United States from any or all attack by foreign or domestic forces, and forswear any form of allegiance or obedience to the Japanese emperor, to any other foreign government, power or

organization?"

As the so-called No-no boy who answers two times 'no' to both of two loyalty questions, Ichiro Yamada is enforced to be imprisoned for two years in federal prison to a Japanese American neighborhood of Seattle even after spending two-years at internment camp. For Ichiro Yamada, American dream remains elusive not as a potential place but as an "imagined" place that can never be reached.

He [Okada] resists an ending rooted in a utopian moment by neither privileging the "post" nor accepting that a status for Japanese Americans of social exclusion internal to the nation is over. Such an elusive nature of Okada's rendition of Ichiro's suburban fantasies - both desirous of a specific moment "beyond" and skeptical of it - is at the heart of No-No Boy. (Sungho Yoon)

Therefore, Francisco Delgado insists, "Ichiro remains neither Japanese nor American and cannot foresee an identity for himself that conjoins these two halves." Carlos Bulosan also gives his speech to the newly arrived Filipino immigrants as follows.

We who came to the United States as immigrants are Americans too. All of us were immigrants- all the way down the line. We are Americans all who have toiled for this land, who have made it rich and free. But we must not demand from America, because she is still our unfinished dream... Instead we must sacrifice for her: let her grow into bright maturity through our labors. If necessary we must give up our lives that she might grow unencumbered.

The description of America as an ambiguous ideal now produces the newly created third place which is transnational or diasporic subject which neither belongs to the ethnic subject nor to the bicultural subject. Amy Tan's The Joy Luck Club and Maxine Hong Kingston's The Woman Warrior are the attempts to create this transnational subject. The narrators' borrowing of old Oriental wisdom such as Hua Mulan and stories from the Cantonese and of the Qing dynasty are originally used to emphasize the both American and Asian logics. Yet like an imagined California as "Diamond Mountain," this idealized Asian kingdom does consolidate neither Asianness nor Americanness. As the result, the young narrators in Amy Tan's and Maxine Hong Kingston's fiction rather stick to the principle of neither/nor logic.

This dialectics between 'where you are from' and where you are at, as Paul Gilroy suggests, the essential characteristics of Asian American literature which oscillates between migration narratives and sojourning narratives or between the relations with the homeland and allegiances to the host land. Both/and logic in Asian 
American literature usually creates the delayed or disillusioned American dreams to both ethnic subjects and assimilationists. Amy Tan's and Maxine Hong Kingston's fiction attests to description of America as the space of others even for the Asian writers born in America. As Sungho Yoon argues, in this regard Asian American literature remains 'the underdog literature' unless it transcends the categories of the national or ethnic identities. Asians within ethnic limitations are usually doomed to be stereotyped as either violent and independent Fumanchu type or funny and assimilationist Charley Chan type.

By finding the newly created third space which neither belongs to America nor to Asia, the richer cultural interpretation can be dialectically completed. In this third space, the migration or locality is no more important to the media or language or imagination. The imagined community, as Benedict Anderson insists, is based on communication and a deep, horizontal comradeship and so the fraternity in this imagined community can be achieved by giving up the traditional concepts of nationality. Similarly, Walter Benjamin in "The Task of the Translator" expresses the concept of "origin of pure language" which does not belong to the host language neither to the colonized language: "The task of the translator consists in finding that intended effect upon the language into which he is translating which produces in it the echo of the original."

\section{The Transnationality of Asian American Literature}

The diasporic or transnational subject is the result of this neither/nor logic of imagined community and the origin of pure language. Don Lee's narrator in "Yellow" lives in a fictional California town of Rosarita Bay in which the Asian immigrants' third generation protagonist Danny Kim's post-immigrant examination of identity finds its solution in a diasporic or transnational subject. In the multicultural society where the ethnic conflict and discrimination still exists, Danny Kim effectively uses his strategy of neither/nor logics and Don Lee suggests that the ethnicity-free space can be the most creative one for Asian American writers.

I'd like to see us get to the point where Asian American authors can have Asian American characters and a big deal isn't made about it, or at least so it's not the first thing mentioned. When I think of, say, Gary Shteyngart, Nicole Krauss, Michael Chabon, and Aimee Bender, I don't think of them as Jewish writers who write about the Jewish experience. I think of them as good writers who write interesting books, period. But I have sometimes wondered how much of the ghettoization of Asian American writers has been self-inflicted. Maybe the onus is on us to branch out more from writing about race and identity, immigration and assimilation, or setting our stories in the ancient hinterlands of China or Japan or Korea. I think Kazuo Ishiguro, one of my heroes, is a good model. His best work has nothing to do with Japan or being a 1.5 Japanese Englishman. (Don Lee. "Don Lee")

Don Lee's this kind strategy of conscious distancing himself of racial issue is not avoiding the racial issue. Instead, his neither/nor logic to find the third blurred space is a wise solution to the conundrum of the either/or choice in the essential issues such as gender or race. M.A.R. Habib succinctly explains the problem of "the law of the excluded middle" which forbids the middle ground:

One must be either a man or not a man; either American or not-American; either Muslim or Jew; either good or bad; either for or against. Hence these "law," which unfortunately still largely governs our thinking today, are not only coercive but encourage a vision of the world as divided up sharply into categories, classes, nations, races, and religions, each with its own distinctive essence or character. So deeply rooted is this way of thinking that even attempted subversions of it, such as those issued from Marxism, feminism, deconstruction, and psychoanalysis, must operate within a broader network of complicity with what they challenge.

In Don Lee's short story of "Yellow," the broader network of neither/nor logic is ironically found in the Korean young man's hating of Korean tradition to be closer to white.

His tastes tended toward what he thought was more sophisticated prose-Conrad, Lawrence, Flaubert, Henry James, Fitzgerald - and hence his diction became strangely Anglicized, his expressions formal and stilted. Increasingly, and with unabashed condescension, he would correct his parents' English. Unlike his brother, Eugene, and sister, Lily, he refused to learn any Korean, and when it was used in the house, he would sometimes burst out, "Speak English! Speak English!" His scorn even extended to his mother's 
cooking: he would not eat any traditional dishes like pindaettok or kimchi, afraid the sharp smells of red pepper and garlic would linger on him. He rarely brought any of his few friends home with him.

But his continuous failure in making a harmonious relation with white girls also let him recognize that he cannot overcome the skin color of "yellow." In this story, the yellow is actually the last word that the protagonist Danny Kim wants to hear in real life. Yet Danny Kim hears this scoffing word when he fights with a non-Asian boxer in the ring. By violently reacting against the mockery, Danny defeats the tough opponent which he might not have won without being so incited. In this way Danny's boxing works as an alternative way to express himself, which was often suppressed by social constraints. Danny's way to control also comes from boxing, like Coleman Silk, the hero of Philip Roth's The Human Stain. Just as the protagonist Coleman Silk tried to avoid the either/or choice suggested in the binary opposition of white/black implication of the name, Danny Kim now looks at the third space through which he does not have to become either yellow or white. Unlike Coleman Silk who finds the passing as the solution, however, Danny Kim learns to act cool like Portillo, his Hispanic boxing trainer.

Danny found himself imitating him. The key seemed to be a lack of excess, a measured slowness, in everything Portillo did. He looked like he'd never been in a hurry in his life. He embodied absolute stoicism: giving in to emotion made you weak. What he ultimately said to you was this: I don't need you. And that in itself, that sort of self-possession, attracted you to him.

Danny's comment on his Korean wife Rachel ("No stereotype is innocent") actually shows that he now slowly begins to possess the confidence in himself which neither belongs to white nor yellow skin color. Rachel's reply of "Racism's not the problem. It's you." also indicates that race is not necessarily a generalized issue but also an idiosyncratic topic of imagined community of transnationality.

In an autobiographic essay collection Tiger Writing, Gish Jen also suggests this imagined transnationality can be a good match with American independent spirit with Asian interdependent self. Simply put, without denying oneself, she says, we cannot experience others. The embryonic space between social order and selfdetermination cannot be achieved with the avarice to become both A and B. Don Lee's "Yellow" is a good example which shows the unavoidable failure in a try to be both white and yellow. By becoming the third space of others (Hispanic trainer in this case) Danny Kim find his true self-possession which can be harmonized with social order. Gish Jen also expresses this kind of becoming imaginary others with estranged landscape as the solution to the racism:

My books were in good individualistic fashion driven by internal conflict-"the human heart in conflict with self," as Faulkner put it-partly because I had learned from my reading that they should be, but partly, too, because I had by this time become well aware of how one might be in conflict with oneself. And if it is not too egregiously self-deluded to say so, it seemed to me that, again as per the artistic agenda of the independent self, my characters were hardly a cardboard figures trotted out in service of some didactic purpose. Yet there I was, in interdependent fashion, clearing out a cultural space for myself as well. In this, I was far less accommodating of society than was, say, Shen $\mathrm{Fu}$, if you recall his Six Records of a Floating Life, and its description of how rooms could be arranged as were the beds on the stern of a boat, so as not to "have a confined feeling at all."

Again ironically, the third place of the Asian American literature can be found in the place where the ethnicity is free to impose either/or choices. The diasporic subject of neither/nor logic will be the future of ethnic literature where passing is not working and where we can find the concept of atopological imagined community described and created by Mizmura Minae's A True Novel.

Yet Mizumura has triumphed in taking a quintessential Western Gothic and making it wholly Japanese. Japan has its own traditions of ghost stories, doomed love and the nobility of despair. The violence that looms beneath surface restraint is a motif running through such varied contemporary works as manga or films like "In the Realm of the Senses." In a way, Mizumura answers one of the philosophical questions she poses in "A True Novel": At least between its pages, Western tradition does not eradicate Japanese literary sensibility. She has drawn on the West for inspiration but created something indelibly, 


\section{irresistibly, Japan's own. (Chira)}

As Minae Mizumura emphasized the multiple values of cultures instead of Culture, we must not fix our identities into one typical race and language. Truth cannot be monopolized by one race and one nation. The multiple truths are most distinctively displayed in the blurred space of literature of transnationality written by Asian Americans "who are condemned to reflect on language" and also on dialectics of inter/independent identities.

If more English native speakers walked through the doors of other languages, they would discover undreamed-of landscapes. Perhaps some of them might then begin to think that the truly blessed are not they themselves, but those who are eternally condemned to reflect on language, eternally condemned to marvel at the richness of the world." (Mizumura, The Fall of Language)

\section{References}

[1] Anderson, B. (1991). Imagined Communities: Reflections on the Origin and Spread of Nationalism. New York: Verso.

[2] Benjamin. W. (1927). "The Task of the Translator." in Illuminations, trans. Harry Zohn; ed. \& intro. Hannah Arendt. NY: Harcourt Brace Jovanovich, 1968.

[3] Bulosan, C. (1946). America is in the Heart: A Personal History. Seattle: University of Washington Press.

[4] Chira. S. (2013). Strange Moors: 'A True Novel,' by Minae Mizumura. New York Times. Sunday Book Review. Dec 13, 2013.

[5] Degado, F. (2012). "Neither Japanese Nor American: Identity and Citizenship in John Okada's No-No Boy." Trespassing Journal: Spring 2012, Issue 1, p 50.

[6] Gilroy, P. (1991). "It ain't where you're from, it's where you're at : the dialectics of diasporic identification. Third World perspectives on contemporary art and culture. No. 13, winter 1991, pages 3-16.

[7] Habib. M. A. R.(2011). Literary Criticism from Plato to the Present: An Introduction. Oxford: Wiley-Blackwell.

[8] Jen, G. (1998). Typical American: A Novel. New York: Vintage Contemporaires.

[9] Kingston, H. (1989). The Woman Warrior: Memoirs of a Girlhood Among Ghosts. New York: A Vintage Book.

[10] Okada, J. (1977). No-no Boy. Seattle: University of Washington Press.

[11] Lahiri, J. (2008). Unaccustomed Earth. New York: Knopf Doubleday Publishing Group.

[12] Lee, C. (1995). Native Speaker. New York: Riverhead Books.

[13] Lee, D. (2012). Yellow: Stories. New York: Norton. Kindle Edition.

[14] ---. "Don Lee: The Ethnic Literature Box." http://www.guernicamag.com/daily/don-lee-the-ethnic-literature-box/

[15] Mizmura, M. (2015). The Fall of Language in the Age of English. Trans. Mari Y. and Juliet W. C. New York: Columbia University Press.

[16] ---. (2013). A True Novel. Trans. from the Japanese by Juliet Winters Carpenter and Ann Sherif. Other Press.

[17] Tan, A. (2006). The Joy Luck Club. New York: Penguin.

[18] Yamamoto, H. (1994). Seventeen Syllables. Brunswick: Rutgers University Press.

[19] Yoon, S.(2012). Writing as an Underdog (in Korean). Seoul: Seoul National University Press. 